\title{
Lysis of Streptococci by an Extracellular Lysin Produced by Competent Group H Streptococcus Strain CHALLIS
}

\author{
By J. M. RANHAND AND R. M. COLE \\ Laboratory of Microbiology, National Institute of Allergy and Infectious Diseases, \\ The National Institutes of Health, Bethesda, Maryland, 20014, U.S.A.
}

(Accepted for publication Io January i972)

INTRODUCTION

Competent cultures of the group $\mathrm{H}$ streptococcus strains CHALLIS and WICKY autolysed in a buffer at $\mathrm{pH} 9$ containing a reducing agent whereas non-competent organisms did not (Ranhand, Leonard \& Cole, I97I). Supernatant fluids of the autolysed competent cultures lysed non-competent WICKY organisms, but were inactive against Hydrogenomonas eutropha, Micrococcus lysodeikticus and a group A streptococcus (strain $60 \times 15$ ). Competence factor (CF) obtained by ammonium sulphate precipitation of supernatant fluids of strain CHALLIS grown in a defined medium (Leonard, Ranhand \& Cole, 1970) was without lytic activity against non-competent WICKY organisms (Ranhand et al. 1971). Sterile supernatant fluids of CHALLIS cultures of declining competence grown for $3 \mathrm{~h}$ in a complex medium (brainheart infusion with horse serum (BHI-HS) and neopeptone) have now been found to contain both $\mathrm{CF}$ and lytic activity against non-competent WICKY organisms. The lytic activity is selectively destroyed by heat $\left(56^{\circ} \mathrm{C}\right.$ for $\mathrm{I} 5$ to $\left.30 \mathrm{~min}\right)$.

The present report explores the range of lytic activity of crude filtered supernatant fluids of competent CHALLIS cultures grown in BHI-HS plus neopeptone as a preliminary step in defining the nature of the presumptive lysin. Some strains of streptococcal serogroups $\mathrm{A}, \mathrm{E}$, $\mathbf{H}$, and $\mathrm{K}$ are lysed, whereas representatives of other streptococcal groups and cultures of Staphylococcus aureus, Bacillus subtilis, and Micrococcus lysodeikticus are not.

\section{METHODS}

Bacteria. Table I lists the cultures used. Some of these were randomly selected from a collection in our laboratory. The group $\mathrm{H}$ streptococcus strain BLACKBURN was obtained from R. Pakula (School of Hygiene, University of Toronto, Ontario, Canada). Organisms designated as serological groups $\mathrm{F}$ (strain 57 ), M, N, P, Q, R and S were obtained from H. Slade (Northwestern University Medical School, Chicago, Illinois, U.S.A.). When possible, the strains were grouped in this laboratory with specific grouping antisera which were obtained from the Center for Disease Control, Atlanta, Georgia, U.S.A., except for that directed against group $\mathrm{H}$ organisms which was prepared in our laboratory. The groups designated with a question mark (?) were not confirmed here owing to a lack of specific antisera.

Culture. Cultures were grown overnight at $37^{\circ} \mathrm{C}$ in $10 \mathrm{ml}$ of brain-heart infusion (Difco Laboratories, Detroit, Michigan, U.S.A.) containing $2 \cdot 5 \%(\mathrm{v} / \mathrm{v})$ heat inactivated horse serum $\left(56^{\circ} \mathrm{C}, 30 \mathrm{~min}\right.$; Microbiological Associates Inc., Bethesda, Maryland, U.S.A.; BHI-HS). All cultures were grown statically except for Bacillus subtilis which was grown with mild aeration. Micrococcus lysodeikticus was obtained from Difco and consisted of organisms 
Table I. Bacterial cultures used

\begin{tabular}{|c|c|c|c|}
\hline Organism & \multicolumn{2}{|c|}{ Strains and/or type } & $\begin{array}{c}\text { *Lysis with } \\
\text { the CHALLIS } \\
\text { lysin }\end{array}$ \\
\hline Streptococcal serological group & \multicolumn{3}{|c|}{ Type I (derived; M protein negative) } \\
\hline A & & $59 \times 161 \dagger$ & \\
\hline A & Type 4 & $60 \times 15 \dagger$ & + \\
\hline A & Type 6 & $56 \times 188 \dagger$ & + \\
\hline B & & $54 \times 548 \dagger$ & - \\
\hline B & & $54 \times 34$ 위 & - \\
\hline B & & $9925 \%$ & - \\
\hline C & & 88 & - \\
\hline C & & 26RP66 & - \\
\hline D & & F24P & - \\
\hline $\mathrm{D}$ & & $55 \times 132 \dagger$ & - \\
\hline $\mathrm{E}$ & & I $2390 \%$ & + \\
\hline $\mathrm{F}$ ? & & $54 \times 505 \dagger^{\dagger}$ & - \\
\hline $\mathrm{F}$ ? & & 57 & - \\
\hline G & & $57 \times 262$ & - \\
\hline G & & $54 \times 264 \dagger$ & - \\
\hline $\mathrm{H}$ & & WICKY & + \\
\hline $\mathbf{H}$ & & BLACKBURN & + \\
\hline $\mathrm{K}$ ? & & $66 \times 6 \dagger$ & + \\
\hline $\mathrm{K}$ ? & & $60 \times 256 \dagger$ & - \\
\hline L? & & D176B & - \\
\hline L? & & $54 \times 419 \dagger$ & - \\
\hline M? & & I39 & - \\
\hline $\mathrm{N}$ ? & & C554 & - \\
\hline $\mathrm{N}$ ? & & $9936 \ddagger$ & - \\
\hline P? & & $54 / 583$ & - \\
\hline Q? & & E6844 & - \\
\hline $\mathrm{R}$ ? & & 734 & - \\
\hline S? & & I 231 & - \\
\hline Bacillus subtilis & & MARBURG & - \\
\hline Staphylococcus aureus & & $6538 \mathrm{P} \dagger$ & - \\
\hline Micrococcus lysodeikticus & & - & - \\
\hline
\end{tabular}

killed with ultraviolet light. In general, $10 \mathrm{ml}$ of an overnight culture was centrifuged for $20 \mathrm{~min}$ at 1000 to $2000 \mathrm{~g}$ at $\mathrm{O}$ to $4^{\circ} \mathrm{C}$ and the pellet was resuspended in $10 \mathrm{ml}$ of fresh BHI-HS. The overnight supernatant fluids were chilled and stored at $-40^{\circ} \mathrm{C}$ to test for the presence of lytic activity against non-competent wICKY organisms. The resuspended pellet was diluted to $5 \%(\mathrm{v} / \mathrm{v})$ in $50 \mathrm{ml}$ of warmed BHI-HS in a $125 \mathrm{ml}$ cotton-stoppered Erlenmeyer flask and incubated at $37^{\circ} \mathrm{C}$ until exponential growth was attained.

At appropriate times, $40 \mathrm{ml}$ of culture was harvested by centrifuging (1000 to $2000 \mathrm{~g}$; 0 to $4^{\circ} ; 20 \mathrm{~min}$ ) and the pellet washed once with $5 \mathrm{ml}$ of cold $0.85 \% \mathrm{NaCl}$. The washed pellet was suspended in $0.8 \mathrm{ml}$ of cold deionized water. Two-tenths $\mathrm{ml}$ of this suspension was then added to the lysing buffer which was $0.5 \mathrm{M}$-TAPS buffer (tris (hydroxymethyl) methylamino-propane sulphonic acid; Calbiochem, Los Angeles, California, U.S.A.) containing $0.2 \mathrm{M}-2$-mercaptoethanol and $0.0 \mathrm{I}$ M-ethylenediaminetetraacetic acid, $\mathrm{pH} 9 \cdot 0-9 \cdot 3$.

Lysis. In general, $0.54 \mathrm{ml}$ of lysing buffer, $0.2 \mathrm{ml}$ of the suspended organisms, and $0.16 \mathrm{ml}$ of either the CHALLIS lysin, or BHI-HS plus I \% (w/v), neopeptone (Difco) or the overnight 
homologous supernatant fluid, or deionized water were mixed together in glass cuvettes and kept at $0^{\circ} \mathrm{C}$. The last three cuvettes were controls. The extinction $(E)$ was then read against a zero of water at $750 \mathrm{~nm}$. with a Beckman Model B spectrophotometer. At this wavelength there was little or no absorption by BHI-HS plus neopeptone. After all zero-time extinctions were obtained, the tubes were incubated at $37^{\circ} \mathrm{C}$ and readings were made every $5 \mathrm{~min}$ for $\mathrm{I} \mathrm{h}$. In most instances, the tubes were incubated overnight and $E$ was again read after I8 h.

Electron microscopy. Lysis was also monitored by examining organisms in the electron microscope after incubation for $18 \mathrm{~h}$ with the CHALLIS lysin. Negative staining was used as already described (Ranhand et al. 1971).

CHALLIS lysin. The CHALLIS lysin was most active in culture supernatant fluids derived from organisms that had passed their peak of competence. CHALLIS organisms were grown overnight at $37^{\circ} \mathrm{C}$ in Io $\mathrm{ml}$ of BHI-HS, then diluted to $5 \%(\mathrm{v} / \mathrm{v})$ into $100 \mathrm{ml}$ of BHI-HS plus $\mathrm{I} \%(\mathrm{w} / \mathrm{v})$ neopeptone in a $250 \mathrm{ml}$ cotton-stoppered Erlenmeyer flask. The bacteria were incubated at $37^{\circ} \mathrm{C}$ for $3 \mathrm{~h}$ then centrifuged (I000 to $2000 \mathrm{~g} ; 0$ to $4^{\circ} \mathrm{C} ; 20 \mathrm{~min}$ ) and the supernatant fluids were filtered twice. The first filtration was through a $0.8 \mu \mathrm{m}$ membrane (type GA-4; Gelman Instrument Co., Ann Arbor, Michigan, U.S.A.) for further clarification of the supernatant fluid, and the second filtration was for sterilization ( $0.22 \mu \mathrm{m}$ membrane; no. 7103 , Falcon Plastics, Los Angeles, California, U.S.A.). The sterile crude lysin $(0.3 \mathrm{ml})$ was stored at $-40^{\circ} \mathrm{C}$.

\section{RESULTS}

Initial lysis experiments employed overnight cultures of the group $\mathrm{H}$ organisms as substrate for the lysin, but lysis was slow. With organisms harvested in the exponential phase of growth as substrate, lysis was relatively rapid. Table $\mathrm{I}$ gives the lytic response of all cultures tested.

Lysis, which was not observed without the addition of the CHALLIS supernatant fluid, was manifested as a decrease in $E$ and an increase in viscosity. In all controls there was a slight decrease in $E$ that never exceeded $40 \%$ (after overnight incubation) without visible increase in viscosity. The reason for the decrease of $E$ is not clear but may be due to a number of factors such as $\mathrm{pH}$, ionic strength, osmolality, molarity, or the chemical composition of the suspending solution. Autolysis was not apparent with any of these cultures except for competent CHALLIS and SBE I/II organisms.

The rate and extent of lysis for all three group A strains $(59 \times 16 \mathrm{I}, 60 \times 15,56 \times 188)$ was about equal. In $60 \mathrm{~min}$, the $E$ decreased by about $60 \%$ and reached $25 \%$ of the starting $E$ during the overnight incubation period. The single group E streptococcal strain (I2390) also lysed. By $60 \mathrm{~min}$, the $E$ decreased $75 \%$. Of the two strains of group K organisms tested, only one lysed $(66 \times 6)$. At $60 \mathrm{~min}$, there was a $45 \%$ decrease in $E$ which upon overnight incubation had become a $72 \%$ decrease. Another group K strain $(60 \times 256)$ was refractory to the action of the lysin. The fact that some strains of a given group are lysed by the enzyme and others are not, may reflect group heterogeneity in their cell-wall composition as alluded to by Colman \& Williams (1965).

Both group $\mathrm{H}$ strains, wICKY and BLACKBURN, lysed with the CHALLIS enzyme. WICKY organisms however, were more sensitive. In $60 \mathrm{~min}$, these cultures lost $80 \%$ of their initial $E$ and more than $90 \%$ in $18 \mathrm{~h}$. The BLACKBURN organisms decreased $60 \%$ in $60 \mathrm{~min}$ and about $70 \%$ in $18 \mathrm{~h}$. The other organisms listed in Table I were not lysed by the challis lysin.

None of the organisms tested lysed when incubated in lysing buffer containing a sample $(0.16 \mathrm{ml})$ of their respective overnight supernatant fluids. However, lytic activity against 
non-competent WICKY organisms was present in overnight culture fluids derived from CHALLIS, SBE I/II, and from the group D streptococcus strain $55 \times 132$.

\section{DISCUSSION}

In a previous report (Ranhand et al. I97I) we showed that only competent group H strains autolysed in a buffer at $\mathrm{pH} 9$ containing 2-mercaptoethanol. Recent assays of sterile competence factor-containing solutions prepared in complex media, as well as overnight culture fluids from CHALLIS organisms that lacked competence factor activity, revealed that these contained lytic activity against non-competent WICKY organisms. Since lysis of streptococcal organisms has always been a topic of interest to us and a number of other investigators (Barkulis, Smith, Boltralik \& Heymann, 1964; Shockman, Pooley \& Thompson, 1967, Coleman, van de Rijn \& Bleiweis, 1970), and, since an extracellular lysin derived from group $\mathrm{H}$ organisms has never been before described, we undertook the survey to see whether the lysin was group or genus specific.

The data presented in this report, although limited to some few strains from I 6 serological groups of Streptococcus and three strains from other Gram-positive genera, show that the lysin is active only on bacteria from serological groups $\mathrm{A}, \mathrm{E}, \mathrm{H}$, and $\mathrm{K}$. Although we do not know the nature of the substrate for the lysin, we can tentatively suggest that it is limited to the cross-wall region (Ranhand et al. I97I). In susceptible organisms, the CHALLIs lysin, as well as the autolysin of competent organisms (Ranhand et al. 1971), does not cause the complete dissolution of the cell wall but appears to act only at a limited site of cross-wall formation. Kinetic data (to be presented in another communication) suggest that the CHALLIS lysin is the autolysin of competent organisms. That they are one and the same enzyme is also indicated by the conditions in which they are active - high $\mathrm{pH}$ value in the presence of a reducing agent.

\section{REFERENCES}

Barkulis, S. S., Smith, C., Boltralik, J. J. \& Heymann, H. (I964). Structure of streptococcal cell walls. IV. Purification and properties of streptococcal phage muralysin. Journal of Biological Chemistry 239, 4027-4033.

Coleman, S. E., van de Rijn, I. \& Bleiweis, A. S. (1970). Lysis of grouped and ungrouped streptococci by lysozyme. Infection and Immunity 2, 563-569.

Colman, G. \& Williams, R. E. O. (I965). The cell walls of streptococci. Journal of General Microbiology 4r, $375-387$.

Leonard, C. G., Ranhand, J. M. \& Cole, R. M. (1970). Competence factor production in chemically defined media by noncompetent cells of group $\mathrm{H}$ streptococcus strain CHALLIS. Journal of Bacteriology I04, 674-683.

Ranhand, J. M., Leonard, C. G. \& Cole, R. M. (197I). Autolytic activity associated with competent group $H$ streptococci. Journal of Bacteriology ro6, 257-268.

Shockman, G. D., Pooley, H. M. \& Thompson, J. S. (1967). Autolytic enzyme system of Streptococcus faecalis. III. Localization of the autolysin at the sites of cell-wall synthesis. Journal of Bacteriology 94 , $1525^{-1} 530$. 